Printed in Nigeria

\title{
Serum Level of Antioxidant Vitamins (Vitamin A, C and E) in Plasmodium falciparum Malaria Infected Children in Owerri, Eastern Nigeria
}

\section{Raphael C. EKEANYANWU ${ }^{1 *}$, Nkem ACHUKA ${ }^{1}$ and Benjamin U. AKPOILIH ${ }^{2}$}

\author{
${ }^{1}$ Biochemistry Unit, Department of Chemical Sciences, Novena University, Ogume, Delta state \\ ${ }^{2}$ Microbiology Unit, Department of Biological Sciences, Novena University, Ogume, Delta state
}

Received September 11, 2009

MS/No BKM/2009/050, ( 2009 Nigerian Society for Experimental Biology. All rights reserved.

\begin{abstract}
The levels of antioxidant vitamins were estimated in Plasmodium falciparum malaria infected children. Forty-three children with P.falciparum infection were selected based on the clinical symptoms. Twenty-two apparently healthy children with no malaria parasitaemia were included as the control subjects. P.falciparum parasitaemia and serum levels of the antioxidant vitamins (vitamin A, $\mathrm{C}$ and $\mathrm{E}$ ) were determined using standard procedures. It was observed that all parameters measured were significantly lower in malaria infected children when compared with the respective control values. The relationship between malaria parasitaemia and serum concentration of vitamin $\mathrm{E}$ were positively correlated $(\mathrm{r}=0.42)$, but vitamin $\mathrm{A}(\mathrm{r}=-0.05)$ and $\mathrm{C}(-0.06)$ were negatively correlated. Children within 0-5 years of age had higher malarial parasitaemia $(7379.82 \pm 91899 / \mu \mathrm{L})$ than those between 6-12 years of age $(5026.19 \pm 1514.58 / \mu \mathrm{L})$, and these children had lower concentrations of vitamin A $(21.27 \pm 8.68 \mu \mathrm{g} / \mathrm{dL}), \mathrm{C}(0.45 \pm 0.19 \mathrm{mg} / \mathrm{dl})$ and $\mathrm{E}(0.69 \pm 0.22 \mathrm{mg} / \mathrm{dL})$ when compared with children between 6-12 years (vitamin $\mathrm{A}=25.19 \pm 8.12 \mu \mathrm{g} / \mathrm{dL}$, vitamin $\mathrm{C}=0.53 \pm 0.16 \mathrm{mg} / \mathrm{dL}$ and vitamin $\mathrm{E}=0.86 \pm 0.41 \mathrm{mg} / \mathrm{dL}$ ). Results suggest that in Owerri, Eastern Nigeria, the degree of malaria parasitaemia in especially children between 0-5 years could comprise immunity (as judged by the correlation) and reduce serum antioxidant vitamin levels. Health care providers should recognize these effects in planning malarial treatment and control programs. Changes in serum antioxidant levels during post-treatment periods should be investigated and documented.
\end{abstract}

Keywords: Vitamin A, Vitamin C, Vitamin E, Plasmodium falciparum, Children.

*To whom correspondence should be addressed. E-mail: ekeanyanwuraphael@ yahoo.com Tel: +2348032744572 


\section{INTRODUCTION}

Malaria is essentially a tropical disease occurring in regions between latitude $62^{0} \mathrm{~N}$ and $40^{\circ} \mathrm{S}$ with an altitude of $1,500 \mathrm{~m}$. This region is formed mainly within the tropics and subtropics and this makes malaria endemic in this zone ${ }^{1}$. There are two epidemiological extremes of malaria known as stable and unstable malaria ${ }^{2}$. Epidemiological factors that make malaria endemic in the tropics include climatic factors (relative humidity, altitude, rainfall level, mean temperature between 18$19^{\circ} \mathrm{C}$ ) and socioeconomic factors, as all these have effects on the availability of vectors which maintain that transmission of malaria ${ }^{2}$. Malaria can be transmitted by three known ways; vector transmission ${ }^{3}$, blood transfusion ${ }^{4}$ and Congenital transmission ${ }^{5}$. Malaria is caused by the plasmodium species and is a major cause of morbidity and mortality in developing countries ${ }^{6}$. It affects $300-500$ million people and kills 1.5 - 2.7 million people annually. The majority of these cases are children where the disease can exist in a severe form, often with devastating consequences ${ }^{7}$.

The wide spectrum of malaria morbidity and mortality is dependent largely on the complex pathogenesis of this parasitic infection. Micronutrient statuses have been shown to influence resistance to several infectious diseases including measles and diarrheal and respiratory disease ${ }^{8,9}$. Micronutrients are known to influence the disease progression in man. For instance, a randomized trial has shown that periodic Vitamin A supplementation could reduce the incidence of febrile episodes and parasitaemia due to Plasmodium falciparum in Papua, New Guinea $^{8}$. Vitamin A is essential for normal immune function and has been shown to influence both antibody responses and cell mediated immunity ${ }^{10}$. Strong antioxidants such as dietary carotenoids and Vitamin E have been shown to modulate immune functions in humans. Vitamin $\mathrm{C}$ concentrations correlated with white cell count, alpha-1- acid glycoprotein and IL-6, all of which are markers of inflammation ${ }^{11}$. Vitamin $\mathrm{C}$ can also rejuvenate Vitamin $\mathrm{E}$, making it an indirect contributor to fighting free radical damage in membrane lipids ${ }^{12}$. These free radicals are products of oxidative stress that is aggravated in malarial infection to decrease the antioxidant defence system. One of the consequences of oxidative stress is the development of malarial anaemia ${ }^{13,14}$. Thus the overall antioxidant status will give more relevant biological information compared to that obtained by the measurements of individual components ${ }^{15}$. In Caucasians, a reference range of $1.30-1.78 \mathrm{mmol} / \mathrm{L}$ has been reported ${ }^{16}$. Akpotuzor et al. ${ }^{15}$ reported an Antioxidant range of $0.84-1.68 \mathrm{mmol} / \mathrm{L}$ in Nigerian subjects.

It has been argued that vitamin E deficiency might be protective against malaria in mice ${ }^{17}$, but this relationship in humans is not well understood. It has been documented that antioxidants such as carotenoids and Vitamins $\mathrm{C}$ and $\mathrm{E}$ could provide protection against oxidative stress induced by malaria ${ }^{18}$. Despite the role of these antioxidants could play in malarial pathogenesis, there is limited information on the antioxidant profile among children with $P$. falciparum malaria in Nigeria and Owerri in particular. To gain insight into this, we investigated the antioxidant profile among Nigerian children diagnosed with $P$. falciparum malaria and studied the correlation between antioxidant concentrations and malarial parasitaemia.

\section{MATERIALS AND METHODS}

The study was conducted in Owerri, Imo State, Nigeria, between June 2009 and August 2009. Owerri town lies on latitude $5.485^{\circ} \mathrm{N}$ and longitude $7.035^{\circ} \mathrm{E}$ and is located in a rainforest belt of Imo State, endemic for Plasmodium falciparum malaria parasite which is transmitted by the female Anopheles mosquito. It has a rainy period from April to November which is when the bite of mosquitoes is more rampant. The rainforest belt where the state is located is also a very good site for mosquito habitat. Owerri has a population comprising workers in the private sector, civil servants, students, traders, self employment etc. The study subjects consist of sixty-five children between the ages of 1-12 years who attended the pediatric clinic of Federal Medical Centre, (FMC) Owerri, Nigeria. The study subjects were children (43) infected with Plasmodium falciparum malaria parasite, who reported ill with fever (axillary temperature $>37.5^{\circ} \mathrm{C}$ ), headache, vomiting, diarrhea, respiratory 
distress and other clinical signs and symptoms of malaria, as previously documented ${ }^{19}$ and also have not been placed on any anti-malaria drug. The children who did not meet these criteria were excluded from the study. Apparent healthy children, consisting of 22 subjects who were found to be negative for Plasmodium falciparum in their peripheral blood were used as controls. Both groups of subjects must have resided in the city of Owerri for at least one year before the study. The scope nature and objective of the investigation were thoroughly explained to the parents/guardian of the children for their consent, which was sought and obtained.

Plasmodium falciparum parasitaemia was determined in peripheral blood smears stained by Giemsa stain. The thick and thin films were analysed for the number of parasites per 200 white blood cells. Slides were considered negative if no parasites were seen in 100 fields in the film. Serum Vitamin A assay was by the method of Olson et $a .^{20}$, serum Vitamin E assay was by the method of Kaser and Stekol $^{21}$, and serum Vitamin C assay was by the method of Roe and Kuether ${ }^{22}$. The data obtained in this investigation were subjected to statistical analysis.

\section{RESULTS}

The antioxidant profile and intensity of infection (malarial parasitaemia) of the volunteers are presented in Table 1. The control children had higher mean concentration of vitamin A $(51.82 \pm 1209 \mu \mathrm{g} / \mathrm{dl})$ and these differences were statistically significant at $p<0.05$ when compared with the infected counterparts. The mean concentrations of vitamin $\mathrm{C}(1.01 \pm 0.17$ $\mathrm{mg} / \mathrm{dl})$ and vitamin $\mathrm{E}(0.96 \pm 0.22 \mathrm{mg} / \mathrm{dl})$ in the control children were statistically significant $(p<0.05)$ when compared with their infected counterparts. The relationship between malarial parasitaemia, vitamin $\mathrm{A}$ and the vitamin $\mathrm{C}$ were negatively correlated with $\mathrm{r}=$ 0.05 and $r=-0.06$, respectively. The level of vitamin $\mathrm{E}$ strongly and positively correlated with the malarial parasitaemia $(r=0.42)$. The antioxidant vitamins profile and malaria parasitaemia according to the age of the infected and control children are presented in Table 2.

Table 1: The changes in antioxidant vitamins (A, C and E) induced by $P$. falciparum malaria infection

\begin{tabular}{|c|c|c|c|c|}
\hline Intensity of infection & $\mathrm{n}$ & $\begin{array}{l}\text { Vitamin A } \\
(\mu \mathrm{g} / \mathrm{dl})\end{array}$ & $\begin{array}{l}\text { Vitamin C } \\
(\mathrm{mg} / \mathrm{dl})\end{array}$ & $\begin{array}{l}\text { Vitamin E } \\
(\mathrm{mg} / \mathrm{dl})\end{array}$ \\
\hline $\begin{array}{c}\text { (Mild/Moderate }<7000 \mu / \mathrm{L}) \\
5158.06 \pm 1430.92\end{array}$ & 36 & $24.42 \pm 8.12$ & $0.51 \pm 0.17$ & $0.87 \pm 0.40$ \\
\hline $\begin{array}{c}(\text { Severe }>7000 \mu / \mathrm{L}) \\
8038.57 \pm 631.31 / \mu \mathrm{L}\end{array}$ & 7 & $22.86 \pm 9.48$ & $0.52 \pm 0.21$ & $0.59 \pm 0.16$ \\
\hline $\begin{array}{c}\text { (Mean infected volunteers) } \\
5626 \pm 1709.09\end{array}$ & 43 & $24.16 \pm 8.26^{*}$ & $0.51 \pm 0.17^{*}$ & $0.82 \pm 0.38 *$ \\
\hline $\begin{array}{c}\text { (mean control volunteers) } \\
0.00 / \mu \mathrm{L} \\
\end{array}$ & 22 & $51.82 \pm 12.09$ & $1.01 \pm 0.17$ & $0.96 \pm 0.22$ \\
\hline
\end{tabular}

Values are reported as mean $\pm S D$ for ' $n$ ' number of children, *, means values are significantly different $(p<0.05)$ compared with the control, $n=$ number of subjects.

Table 2: The antioxidant vitamins profile and malaria parasitaemia according to the age of the infected and control children

\begin{tabular}{|l|l|l|l|l|l|l|}
\hline & $\begin{array}{l}\text { Age } \\
\text { (years })\end{array}$ & $\begin{array}{l}\text { Vitamin A } \\
\mu \mathrm{g} / \mathrm{dL}\end{array}$ & $\begin{array}{l}\text { Vitamin C } \\
\mathrm{mg} / \mathrm{dL}\end{array}$ & $\begin{array}{l}\text { Vitamin E } \\
\mathrm{mg} / \mathrm{dL}\end{array}$ & $\mathrm{n}$ & $\begin{array}{l}\text { Malaria } \\
\text { Parasitaemia/ } / \mu \mathrm{L}\end{array}$ \\
\hline \multirow{2}{*}{$\begin{array}{l}\text { Infected } \\
\text { subjects }\end{array}$} & $0-5$ & $21.17 \pm 8.68^{*}$ & $0.45 \pm 0.19^{*}$ & $0.69 \pm 0.22^{*}$ & 11 & $7379.82 \pm 918.99$ \\
\cline { 2 - 7 } & $6-12$ & $25.19 \pm 8.12^{*}$ & $0.53 \pm 0.16^{*}$ & $0.86 \pm 0.41^{*}$ & 31 & $5026.19 \pm 1514.58$ \\
\hline \multirow{2}{*}{$\begin{array}{l}\text { Control } \\
\text { subjects }\end{array}$} & $0-5$ & $51.60 \pm 12.51$ & $0.93 \pm 0.15$ & $0.91 \pm 0.30$ & 10 & - \\
\cline { 2 - 7 } & $6-12$ & $52.0 \pm 12.29$ & $1.08 \pm 0.16$ & $1.01 \pm 0.11$ & 12 & - \\
\hline
\end{tabular}

Values are reported as mean $\pm S D$ for ' $n$ ' number of children, *, means values are significantly different $(p<0.05)$ compared with the control, $n=$ number of subjects. 
Children between 0-5 years old had the highest Plasmodium falciparum load of $7379.82 \pm$ 918.99 in their peripheral blood. Also, these children had a lower vitamins E concentration $(0.69 \pm 0.22 \mathrm{mg} / \mathrm{dl})$ than those between $6-12$ years of age $(0.86 \pm 0.41 \mathrm{mg} / \mathrm{dl})$. The vitamin A $(21.27 \pm 8.68 \mu \mathrm{g} / \mathrm{dl})$ and vitamin $\mathrm{C}(0.45 \pm$ $0.19 \mathrm{mg} / \mathrm{dl}$ ) were lower in younger children within 0-5 years but were higher in those children between $6-12$ years when compared. However, there was significant difference $(p<0.05)$ in the Vitamin A, C and E levels of the malaria infected children, 0-5years of age and 6-12 years of age compared with their control counterparts.

\section{DISCUSSION}

The antioxidant vitamin levels in malaria patients were lower than the levels for control. The lower values observed in antioxidant vitamin levels in malaria may be attributed to increased utilization of the host's serum antioxidants by the malaria parasites to counteract oxidative damages ${ }^{15}$. It was observed that vitamin A concentration in $P$. falciparum infected children was significantly lower $(p<0.05)$ than in the control subjects (Table 1). This observation confirms earlier reports $^{7,23}$. This study however, implicates vitamin A deficiency as an important component of $P$. falciparum in Owerri, Eastern Nigeria. This observation is considered valid considering the role of vitamin $\mathrm{A}$ as an essential micronutrient for normal immune function, which influences antibody responses and cell mediated immunity ${ }^{7,10}$.

The lower concentrations of vitamin A and vitamin $\mathrm{C}$ observed among 0-5 years old children correlated with higher malarial parasitaemia. From present study, a lower concentration of vitamin $\mathrm{E}$ in the serum $P$. falciparum-infected children was observed than that of the control volunteers (Table 1). This agrees with the investigation of Nmorsi, et $a l^{7}$ performed in Ekpoma, Edo state, Nigeria and Das et al. ${ }^{12}$ performed in India, where they documented that children with both severe and mild malaria had significant lower plasma vitamin $\mathrm{E}$ concentrations than the control children without malaria. The low concentration of antioxidant vitamin $\mathrm{E}$ and $\mathrm{C}$ in the infected children may be in part due to increased utilization of serum antioxidants or increased destruction during the malaria infection. Their transfer to red blood cell membrane to counteract the increase oxidative stress during acute phase of the disease by inhibiting membrane lipid peroxidation may be a contributing factor ${ }^{7}$.

It was observed that the children within the first 5 years of age had lower concentrations of vitamin $\mathrm{E}$ than those between 6-12 years who had lower parasitaemia (Table 2). But previous investigation carried by Nmorsi et al. ${ }^{7}$ showed that the children within the first 5 years of age had higher concentrations of vitamin $\mathrm{E}$ than those 6-12 years of age who had lower parasitaemia. They concluded that these micronutrients, which increased with higher malarial parasitaemia, may have protective effects against malaria in their Ekpoma region. This lends support to an earlier hypothesis that antioxidants such as vitamin E may offer protection against the oxidative stress induced by malaria infection ${ }^{24}$. However, Metzger et al. ${ }^{25}$ observed that low concentrations of vitamin $\mathrm{E}$ in serum were not associated with parasite clearance, which is not consistent with the hypothesis that low vitamin E status is protective against malaria ${ }^{17}$.

Overall, the depressed antioxidant concentrations in the children who had malaria indicated the impact of $P$. falciparum infection on the antioxidant status of children in Owerri, Eastern Nigeria. This observation adds to the accumulating reports ${ }^{7,25,26,28}$. This observation can be further proved valid by the deduction of Akpotuzor et $a l^{15}$ and Nmorsi et $a l^{7}$ who indicated that antioxidants are used to counteract the effects of free radicals generated in the presence of malaria. This also explained the negative correlation reported between the intensity of infection and the antioxidant concentrations among the infected children in our study area.

This pattern of antioxidant status is a reflection of the malarial pathogenesis, which involves the invasion of human erythrocytes by the malaria parasite. This brings about metabolic changes in the host cell. The host cells may then become vulnerable to damage due to toxic metabolites derived from both host and parasites. Reactive oxygen species generated in the host-parasite interaction cause the lysis of erythrocytes and alteration of 
antioxidants $7,27,29$ thus leading to the development of malarial anemia ${ }^{7,13,14}$.

From our observations in this study, the serum concentrations of antioxidant vitamins were reduced in malaria and reduction of these antioxidants in turn caused the reduction of the total antioxidant levels of malaria-infected children. It was also noted however that antioxidant levels in our controls were higher than values observed in infected subjects. However, lowered levels of antioxidants, especially of vitamin $\mathrm{C}$ in malaria infection also suggest lowered immunity of host which may be responsible for some of the complications of malaria infection. The reduction of these antioxidants in the stages of malaria infection may expose the children to free radical attack. To reverse this condition and reduce the morbidity due to Plasmodium falciparum, it is necessary to recommend antioxidant agents (particularly vitamin C) as a component of drugs for treatment of malaria infection. Foods rich in antioxidants such as vegetables, fruits (oranges, banana, apples, etc), red palm oil and so many more should also be part of diet recommended for the management of malaria and the outcome of such supplementation should be investigated and derived, documented for further advice.

\section{REFERENCES}

1. Walter, B. J and Davis, J. E. (1976) Malaria parasite, Historical background. $3^{\text {rd }}$ Edn. W.B Saunders. Medical Parasitology pp: 275.

2. Bulter, D. (1996) Time to put malaria control on the global agenda. Nature, 386: $535-536$.

3. Anderson, G., Morton, C. and Green, I. (1981) Parasites and Human Diseases. In:Community Health. $3^{\text {rd }}$ Edn., Chuechill Livingstone, U.S.A. pp: $45-68$.

4. Strickland, G. T. (1991) Life cycle of malaria parasite. $7^{\text {th }}$ Edn. W.B Saunders.Trop.Med., pp: $586-601$.

5. Ezechukwu, C., Ekejindu, I., Ugochukwu, E and Oguatu, M. (2004) Congenitally acquired malaria in hyper - endemic area. A cohot study. Trop.J.Med.Res. 8(2): 44.

6. Krogstad, D. J. (1996) Malaria as a reemerging disease. Epidemiol Rev. 18: 7779
7. Nmorsi, O. P. G., Ukwandu, N. C. D and Egwunyenga, A. O. (2007) Antioxidant Status of Nigerian Children with Plasmodium falciparum malaria. Afri. J. Micro. Res, pp: 061 -064.

8. Hussey, D. C and Clement, C. S (1996) Clinical Problem in measles and management. Ann. Trop. Paediat. 16: 307-317.

9. Black, R. E. (1998) Therapeutic and preventive effects of zinc on serious childhood infectious diseases in developing countries. Am. J. Clin. Nutr. 68 (2):476-479.

10. Semba, R. D. (1998) The role of vitamin $A$ and related retinols in immune function. Nutr. Rev 56: $38-48$.

11. Winklehofor-Roob, B. M., Ellemunter, H., Fruhwirth., Schlese-Haunter, S. E., Kloschsori, G. and Vant, M. A. (1997) Plasma Vitamin $\mathrm{C}$ concentrations in patients with cystic fibrosis, evidence of association with lung inflammation. Am. J. Clin. Nutr, 65: 1858-1866.

12. Das, B. S., Thurnham. D. I., and Das, D. B (1996) Plasma alpha-tocopherol retinol and carotenoids in children with falciparum malaria. Am.J.Clin.Nutr. 64: 94-100.

13. Kremsner, P. G., Greve, B., Lell, B., Luckner, D and Schmid, D. (2000) Malarial anaemia in African children associated with high oxygen radial production. Lancet 355: 40-41.

14. Clark, I. A. and Hunt, N. H (1983) Evidence for the reactive oxygen intermediates causing haemolysis and parasite death in malaria. Infect. Immun. 39: 1-6.

15. Akpotuzor, J. O., Udoh, A. E. and Etukudo, M. H. (2007) Total Antioxidant Status, Vitamins A, C and $\beta$ Carotene levels of Children with P.falciparum infection in University of Calabar Teaching Hospital (UCTH), Calabar. Pak. J. Nutr., 6: 485-489.

16. Miller, N., Rice-Evans, C. and Davies, M. J. (1993) A novel method for measuring antioxidant capacity and its application to monitoring the antioxidant status in premature neonates. Clin. Sci. 84: 407 - 412 .

17. Lavender, A. O. (1992) Selenium and Sulphur in antioxidant protective system 
relationships with vitamin $\mathrm{E}$ and malaria. Proc.Soc.Exp.Biol.Med. 20: 255 - 259.

18. Adelekan, D. A., Adeodu, O. O and Thurnham, D. I. (1997) Comparative effect of malaria and malnutrition on plasma antioxidant vitamins in children. Ann. F.Trop.Paed., 17: 223 - 227.

19. World Health Organization (2008) Severe Falciparum malaria. Tran. R.Soc. Trop. Med. Hyg. 94: 51-59.

20. Olson, J. A. (1979) A simple assay for vitamin $\mathrm{A}$ and carotenoids in human liver. Nutrition 19: 807 - 809.

21. Kaser, E. and Stekol, I. (1943) In Practical Clinical Biochemistry edited by Varley, H and Gowenlock, A.H, Elsevier, Amsterdan, pp: 216.

22. Roe, E. and Kuether, N. (1943). In practical clinical biochemistry edited by H. Varley and A.H Gowenlock, Elsevier, Amsterdan, pp: 254

23. Thurnham, D. I. and Singkamani R. (1991) The acute phase response and vitamin A status in malaria. Trans. $R$. Soc. Trop. Med. Hyg. 85(2):194-199.

24. Clerc, M. (1992) Observations surles vitamins

et/ou antiradicalairesen medicine tropicale. Bull Acad. Nat. Med. 176: 1393-1406.

25. Metzger, A., Gelasius, M., Schankar A., Ndeezi, G, Melikiang, $G$ and Semba, R. (2001) Antioxidant status and acute malaria in children in Kampala, Uganda. Am. J. Trop. Med. Hyg. 65: 15 - 19.

26. Cooper, R., Labadarias, D. and Louw, M. E. (2002) Serum vitamin A and E concentrations in acute falciparum malaria; modulators or markers of severity. Am. J. Clin. Nutr, 64: $94-100$.

27. Erel, K. A, Avei, S., Aktepe, N. and Bulut, V. (1997) Oxidative stress and antioxidant status of plasma and erythrocytes in patients with Vivax malaria. Clin. Biochem. 30: 631-639.

28. Galloway, P., MacMillan, C. and Scatter, N. (2000) Effect of the inflammatory response on trace element and vitamins status. Ann. Clin. Biochem., 37: $289-297$.

29. Allison A. C. and Eugui, I. (1983) The role of cell mediated immune responses in resistance to malaria with special reference to oxidant stress. Ann. Rev. Immunol. 1: 361-392. 